\title{
GREEN MANAGEMENT AND ENVIRONMENTAL SUSTAINABILITY : A CASE STUDY OF ITC HOTEL
}

*Prof Rekha Lakshman

\section{INTRODUCTION}

The challenges related to environment and ecosystem especially due to climate changes are complex, long term and inter related, especially in terms of impact on water and availability of other natural resources. The world is responsible for this and also has the responsibility of protecting the ecosystem with the various programmes and measures related to environment consciousness and environmental sustainability. Various institutions including corporates have come forward to contribute towards this cause. Environment consciousness is nothing but adapting practices, measures and programmes along with producing products and services which are environmental friendly and non- hazardous to the ecology. Environmental sustainability is maintenance of the practices already adopted to protect environment from various hazards.

Many Indian hotels are already working for the cause. They have adopted various measures towards water conservation, efficient discharge of waste, rain water harvesting and so on. This study has been undertaken to understand how hotel industry in India are discharging their responsibilities towards the same, taking ITC hotels as case study.

\author{
**Prof Ramya Manjunath
}

\section{OBJECTIVES OF THE STUDY:}

1. To understand the concern of ITC towards environment protection

2. To understand various measures undertaken by ITC towards environment protection and sustainability

\section{SCOPE OF THE STUDY:}

The scope of the study is limited to ITC Hotels and its environment consciousness.

\section{LIMITATIONS:}

Research has been carried out by using secondary data. It would have been more substantiated if primary data would have been collected using questionnaire or through observation.

Findings:-

The race for unabridged economic growth has left our planet seriously depleted of environmental resources. The world's ecological footprints suggest that the consumption of natural resources every year will be far more than the earth's capacity to regenerate with increasing population. People will have access to limited resources which will be far less than what was available in 1950. The blame game is of absolutely no use. Each

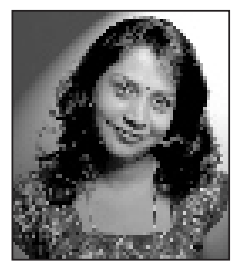

**Prof. Ramya Manjunath

Associate Professor

Sri Sai College For Women

Bangalore 
one on this planet is responsible for global warming and the disaster caused to planet earth, in one way or the other.

It is high time that each one realise this and work for the mitigation of catastrophic disaster caused to planet earth. An attempt has been made in this paper to bring out the fact that how companies all over the world is environment conscious and what strategies they have adopted and sustained towards the same.

Many companies like Sony, ITC, Taj group have not only adopted the best green practices but also create the consciousness among the employees, suppliers, consumers and other stakeholders.

\section{IMPACT OF CLIMATE CHANGE :}

\section{Impact on the water system:-}

Climate change has major and unpredictable effects on the world's water system, including an increase in floods and droughts.

\section{Impact on forests:-}

Due to deforestation by mankind, there is a release of huge carbon dioxide to the environment and other harmful greenhouse gases to the atmosphere. In fact, it is reported that deforestation is so deep that it is dangerous than the emission of every car or truck or plane on the planet.

\section{Impact on food security:-}

Due to climate change there isa significant risk of crop failure, loss of livestock and local food security. The climatic changes sometimes also negatively affect agricultural practices. Indirectly, it also affects human health and livelihood, people's purchasing power, food markets and food security at household levels.

\section{Impact on agriculture:-}

Though many people rely on rain-fed agriculture, it is highly vulnerable to changes in climate variability, seasonal shifts and precipitation patterns.

\section{NATURAL CAUSES OF CLIMATE CHANGE:}

The changes in volcanic activity and changes in solar reduction are episodic and have relatively short term effects on climate but the changes in solar radiance have contributed to climate trends over the past century but since the Industrial revolution, the effect of additions of Greenhouse gases to the atmosphere has been about ten times that of change in the sun's output.

\section{HUMAN CAUSES OF CLIMATE CHANGE:}

According to the Met office, Hadley Centre, UK, "It has been demonstrated beyond reasonable doubt that the climate is changing due to man-madeGreenhouse gases. We are already committed to future substantial change over the next 30 years and changes are likely to accelerate over the rest of the 21 st century.

$4 \%$ of carbon emissions come from industrial processes

$7 \%$ come from agriculture -for example, methane emissions from livestock and manure, and nitrous oxide emissions for chemical fertilisers.

About $40 \%$ of carbon emissions are the result of decisions directly by individuals. The biggest source ofemissions is likely to be

- Energy use in the home ( the main use is heating)

Driving a car

Air travel 
Agricultural activities carried on by humans have been contributing to climate changes, primarily through the production and release of greenhouse gases such as carbon dioxide, methane and nitrous oxide. Even agricultural activities alter the earth's land cover, which can change its ability to absorb or reflect heat and light.

The greenhouse effect is a natural mechanism that retains the heat emitted from the earth's surface. The greenhouse effect is caused by a range of different gases in the earth's atmosphere. Because of the greenhouse effect, the earth is becoming warmer. Due to this, there is occurrence of heat waves and violent downpours. Oceans have risen and the ice at the world's poles and the mountains had begun to melt.

\section{Environmental consciousness of ITC}

With the growth in tourism industry in India, there is a considerable development of the Hotel industry in India. Hotel guests are more conscious of environmental problems and have started to prefer environmental products in their accommodation choice. In this direction, ITC hotel is striving hard for the cause without cutting on client's comforts through the application of the best available practices and technological innovations.

\section{Objectives of environmental consciousness practices of ITC}

1. To integrate the environment as one component of day to day management.

2. To identify significant and priority measures for enabling their implementation and ensuring sustainability over time.

3. To promote rational and eco-efficient use of resources

\section{Practices:-}

1. Rationalising the use of raw materials including water and energy.

2. Reducing the volume of wastes and improving waste management.

3. Adopting a more ecological purchasing policy and improving logistics.

4. Improving the quality of the hotel's internal environment.

5. Making the staff aware of the importance of environmental issues.

Environmental consciousness and sustainability practices of ITC:-

\section{Introduction of ITC:-}

ITC was established on 24thAugust 1910, with itsheadquarters in Kolkata, West Bengal. ITC group of hotels is launched in 1975. The group is of the India's most valuable corporations with sustained performance in creating and enduring value for the nation. Inspired by the vision to sub serve larger goals, ITC has progressively worked towards creating long term shareholder's value, along with the enhancement of societal and environmental capital.

ITC Hotels with its credo of "Responsible Luxury" stands apart not only for its exquisite signature properties, cuisine and service excellence but also being the Greenest Luxury Hotel chain in the world with all ITC's premiumluxury hotels being LEED [leadership in energy and environmental design] platinum certified. In line with this philosophy, ITC Hotels integrate world-class green practices with contemporary design elements to deliver the best of luxury in the greenest possible manner. ITC firmly believes that the future competitiveness of organisation will depend on their ability to adopt effective strategies or a low 
carbon path. ITC has responded to the challenges emerging from the threat of climate change by aligning its corporate strategy with the National Action Plan on Climate Change [NAPCC].

ITC Hotels business maintained its position as one of the fastest growing hospitality chains in India, with more than 100 properties in over 70 locations. It operates under 4 distinct brands-

"ITC Hotels for Luxury", "Welcome Hotels "in the five star segments, "Fortune"in the midmarket to upscale segment and "Welcome Heritage "inthe heritage luxury segment.

ITC's Hotel business, with its world class properties globally benchmarked levels of service excellence and customer centricity is well positioned to sustain its leadership status and emerge as the largest hotel chain in the country over the next 5 years. ITC Hotels was recognised as the most respected company in the hospitality category by the Business World Magazine.

"LEED" Platinum Rating by US Green Building Council-existing building category hotels are ITC Maurya, ITC Windsor, ITC Maurya, ITC Grand Center, ITC Mughal, ITC Sonar, ITC Kakatiya and ITC Rajputana. ITC Hotels has been recognised and Leisure Magazine US. ITC Grand Chola is ranked among the top 50 hotels of the world in the Hot List 2013 and has also the 5 star rating.

ITC has been carrying out green initiatives mainly to reduce Green House Gas Emission through energy conservation, use of renewable source of energy and identifying ways of mitigating the adverse effects of climate change caused by global warming.
ITC has implemented several CDM projects under the Kyoto protocol and has ensured carbon- dioxide sequestration through large scale social and farm forestry initiatives.

\section{ITC's Initiative:-}

\section{ITC has adopted the following strategies for climate change mitigation-}

1. Identify and evaluate climate change risks for each business.

2. Reduce the environmental impact of processes, produce and service and work towards creating apositive environmental footprints.

3. Adopt a low- carbon growth path through reduction in specific energy consumption and enhancing the use of renewable energy sources.

4. Reduce specific water consumption and augment rain water harvesting activities both on site and off site at watershed catchment areas.

5. Work towards minimising waste generation, reuse and recycling and using external post- consumer waste as raw material in those units.

The adoption of those strategies has led to the following outcomes-

ITC has expanded its renewable energy portfolio with $38 \%$ of its energy consumption being met from renewable sources

\section{ITC 's strategy of Waste Management:-}

Often considered to be only an urban phenomenon, inadequate waste management today threatens the quality of life throughout India. Heaps of unattended waste has become a common sight in both urban and rural areas of the country. 
In alignment with ITC's commitment to reduce its environmental impact and create a positive ecological footprint, the hotel has adopted the following approaches on waste management:-

\section{a] Reduction of waste:-}

All ITC units are mandated to reduce specific waste generation through construct, monitoring and improvement of efficiency in material utilisation.

\section{b] Segregation at source-}

All ITC units are required to ensure that all wastes are segregated at source in accordance with company defined guidelines. This ensures maximum reuse and recycling of waste.

\section{c] Effluent Discharge:-}

ITC is committed to achieve zero effluent discharge through treating and recycling of waste water and harvesting of rain water on its properties. This not only reduces fresh water intake but also maintains groundwater recharge.

Thus the issue of waste management has assumed critical significance for the country today. Rapid urbanisation, increasing population, higher consumption levels and inadequate infrastructure are imposing a severe stress on the ecology. A large amount of waste segregated end up in landfills. Apart from the increasing pressure on natural resources, the issue of burgeoning waste also contributes to soil and ground water contamination and Greenhouse gas [GHG] emissions, leading to serious concerns of public health, sanitation as well as large scale environmental degradation. ITC has computed its Green House gas inventory, including GHG emissions and GHG removals in accordance with ISO 14064:2006, which are the latest international standard specifying principles and requirements at the organisational level for quantification and repairing of GHG emission and removal. The 2013-14 inventories has been verified by KPMG at the "Reasonable Assurance Level"

\section{Water conservation:-}

Recognising the daunting challenges arising out of water stress, ITC has adopted the following strategies that focus on the replenishment as well as conservation of this precious natural resource.

\section{a. Assessment of water stress at water stress at ITC units:-}

ITC has undertaken the evaluation of water availability/ stress through "India Water Tool" which will further help in the assessment of water related issues at the site.

\section{b. Water conservation:-}

Conducting water audit, benchmarking and implementation of best practices to achieve the lowest possible specific fresh water intake.

\section{c. Zero effluent discharge:-}

Treating effluent so as to ensure that discharge quality is better than statutory requirements and progressing towards recycling/reusing of all treated effluents.

\section{d. Rain water harvesting:-}

Enhancing our water positive footprint through rain water harvesting, both within our units and across different watershed areas.

\section{e. Water stewardship:-}

Work has been initiated on a pilot basis at the ITC units to work towards meeting the water security need of all stakeholders at the local water shed level

\section{Towards $100 \%$ recycling:-}

Each category of waste is individually addressed and tackled to ensure that it can be reused where 
ever possible, and if not, recycled. This ensures that almost no waste from the business lands up in municipal or private lands.

\section{Creating a positive environmental footprints:-}

Focussed attention on identifying and tracking of all waste streams as well as their characteristics and quantification have helped to ensure the recycling of $99.99 \%$ of the total waste generated in all ITC business units. E.g.:ITC Green Centre at Gurgaon, ITC Maurya, ITC Grand Centre, ITC Windsor ITC Gardenia and so on.

\section{ITC WOW Initiative:-}

It is a recycling initiative that works towards spreading awareness about recycling and encouraging people to segregate and dispose waste responsibly. It is an internationally recognised initiative by Bureau of International Recycling. [ International trade federation representing the world's recycling industry, promoting recycling across the globe.]

\section{ITC Green Centre:-}

ITC Green Centre in Gurgoan, the headquarters of ITC's hotel business is the physical expression of its commitment to sustainabilityecological, social and economical. This building is one of the largest green buildings with space of 17, 000 sq.ft. The ITC Green Centre which was earlier declared as the largest LEED Platinum Rated office space in the world in 2004 was certified in 2012 as the world's highest rated green building with platinum certification by US Green Building Council.

\section{CONCLUSION :}

Over the past few years ITC has become environmental conscious and sensitive towards the climate change and global warming. It has adopted and sustained green practices successfully. Initially there was resistanceabout transforming to more eco-friendly practices due to budget approvals and increased capital cost. But understanding the seriousness of the issue and long term return on investment, made ITC adopt green management practices and sustaining the same. In fact, some green initiatives do not require a high capital cost requirement. It is true that capital expenses will be relatively higher, but there will be a reduction in operational cost on monthly basis. There will be also intangible benefits like conservation of the environment, motivated employees that experience pride at work, enhanced customer loyalty, stronger relationships with communities and regulatory bodies and a trusted brand image.

If all of us come together for this noble cause, time is not far when the earth becomes the best placeto livewithout any pollution and adverse climatic conditions.

\section{SUGGESTIONS :}

1. It is always advisable to identify and review the impact any business operations have on the environment..

2. It is better to involve all employees in all the green practices .

3. Consult and take the advice of External Certification Agencies who have specialised knowledge and experience in sustainability.

\section{REFERENCES :}

www.itchotels.in

www.eai.in

sblf.sustainabilityoutlook.in

www.itcportal.com 